\title{
On the Application of Situational Language Teaching Method to Mongolian English Majors
}

\author{
Juan $\mathrm{Du}^{1}$ \\ ${ }^{1}$ School of Foreign Languages, Inner Mongolia University for Nationalities, Tongliao, Inner Mongolia, China \\ Correspondence: Du Juan, School of Foreign Languages, Inner Mongolia University for Nationalities, Tongliao, \\ China. E-mail: dujuan199507@163.com
}

Received: September 8, 2017 Accepted: October 25, $2017 \quad$ Online Published: November 5, 2017

doi:10.5539/ells.v7n4p98 URL: http://doi.org/10.5539/ells.v7n4p98

\begin{abstract}
The traditional English teaching method has gradually been replaced by new teaching methods in English class. Situational Language Teaching Method is a way to activate the teaching of language knowledge through the design of authentic and concrete situation. A survey is carried out in Inner Mongolia University for Nationalites. It investigates the practical application of Situational Language Teaching Method among Mongolian English majors in this university. Through the analysis of the questionnaire results, the paper reveals the obstacles existing in the application of the method, namely: passive participation due to improper text parsing; weakening role of teachers; and ineffective transfer among language, image and meaning. At the same time, it puts forward appropriate strategies to solve the problems during the application of SLT to Mongolian English majors.
\end{abstract}

Keywords: situational teaching method, Mongolian English major, language transfer

\section{Introduction}

In recent years, efforts have been constantly made to improve the effectiveness of English teaching. However, the traditionally teacher-centered, grammar-translation method still dominates class, and a majority of students regard learning as effortless (Shu, 2009). Situational Language Teaching Method, which was developed from Oral Approach by Harold Palmer and A.S. Hornby, has gradually gained the attention of linguists. Abundant research has been made to support the application of the approach: emotional psychology study shows that personal feelings on cognitive activities at least power, strength, regulate the functions (Turner, 2010); from the view of methodology, situational language teaching method is based on the principle of the reflection theory, which is applied to learners' subjective consciousness. At present, language researchers and teachers in the world attach great importance to the teaching situation. The core idea of situational teaching is the impetus of learning. Bloom (1989) proposed that successful language classroom teaching should create more real life scenarios, so that students have the opportunity to apply what they have learned.

Mongolian English majors especially face the challenge of trilingual acquisition. For them, Mongolian is their mother tongue; Chinese is the second language, and English the third language. According to language transfer theory (Rod, 1994), language transfer not only refers to influence the native language brings but also any other languages the learner has obtained to the new language acquisition. During the process of English learning, Mongolian English learners encounter more multicultural and language obstacles than second language learners do (Odin, 1989, p. 15). As far as domestic teaching media is concerned, $98 \%$ of the available textbooks and auxiliary materials are compiled either in English or in Chinese. Explanation and guidance available is also both in English and Chinese. In some regional universities in China, take Inner Mongolia University for Nationalities as an example, situational teaching method has been adopted in the Mongolian class which set the context, namely, the use of physical, charts, cards, audio-visual equipment to create vivid scene in the classroom teaching. This paper will discuss the present situation of the application of situational teaching method among Mongolian English majors. Through the analysis supported by the data of a survey, it presents proper strategies to solve those problems.

\section{Review of Literature}

\subsection{Theoretical Foundation of Situational Language Teaching Method}

Situational language teaching method has its roots during the late nineteenth and early twentieth centuries in 
England. Its language theory foundation is British structuralism. British Linguist J.R. Firth and M.A.K. Halliday developed powerful view of language in which meaning, context and situation were given a prominent place (Richards, 2000, p. 35). During 1960's, British linguist Sweet considered direct method which was flourished in Europe needed an all-sided methodological basis. So, linguists Sweet, Palmer and Homby summarized the experience of predecessors and in the end they established a whole set of teaching principles and methods which are the basis of situational language teaching method. English teaching process is an essential process of learner's communicative competence. As Comenius (2006) claims that all knowledge begins from the perception of the senses. Through presenting real products, telling stories, playing roles, performing experiment and applying multimedia to create special situations, it combines visual perception and auditory perception together.

Situational language teaching method is characterized by language, action and emotion. At its core is to arouse students' emotion. As teachers' experiment shows, for human being, most of the information is acquired by human vision, and image is the most important visual information source. Its initial application example is Dewey's Five-Step Teaching Method. It consists of five parts. Circumstances (Hint)---Issue--Hypothesis--Inference--Verification (Dewey, 1990, p. 174). Generally speaking, it goes through three stages now: Perception--Comprehend--Deepen. Vivid and intuitive audiovisual method asks learners to be automatic learning instead of passive learning. It motivates students' learning interest and teachers' teaching efficiency as well.

\subsection{Significance of Situational Teaching Method}

Pittman (1963) describes situational teaching as "Our method will be ....situational. The situation will be controlled to teach the new language material... in such a way that there can be no doubt in the learner's mind of meaning of what he hears." (p. 72) The method as in its practice brings students a need for studying with story and enjoyment blended. Compared with traditional models of teaching, it can attract students' attentions which stimulate students' enthusiasm and desire through lively activities. What's more, it gives full play to the subject status of the student and their due rights are fully respected and ensured. Situational teaching method can redeploy students' conscious mental activities and excavate unconscious mental activities. In a relaxed and happy atmosphere, the students' ultimate goal for active and open-minded learning is reached. When learners apply the learned knowledge flexibly to real life, their perceivable life experience and cognitive level are developed. It expends to listening, speaking, reading and writing which greatly increases learners' fundamental language abilities including receptive skills as listening and reading, and productive skills as speaking and writing (Wang, 2000).

\section{Method}

\subsection{Study Design}

This descriptive research (Burns \& Grove, 2003, p. 201) aims to investigate the learning obstacles Mongolians English majors confront in Inner Mongolia University for Nationalities. The author tries to answer the research question: What are the obstacles during the application of situational language teaching method to teaching Mongolian English majors? And what are the relevant strategies?

\subsection{Sample}

A total number of 72 of Mongolian English majors (Grade 2014, 2015 and 2016) and 16 of teachers who are teaching and have the experience of teaching Mongolian English majors from Inner Mongolia University for Nationalities are selected as the sample of this study. The Mongolian students' English score during College Entrance Examination ranges from 60-90, with 150 as full score. Among the teachers, 5 of them are Mongolian who speak Mongolian as their mother tongue, and the rest of the number are not Mongolian.

\subsection{Instruments}

Reflective Practice instrument (Wilkes \& Ashmore, 2014) is applied to assess the obstacles in the situational teaching classes. The study sets demographic questions for both students (series 1) and teachers (series 2) and three-point scale (a few two-point or four-piont). The subjects rated themselves mainly on three-point scale (none/some/a lot). The survey is designed to test the effectiveness of situational teaching method and with the help of the collection of the data, the author can find out the practical problems and possible strategies.

\subsection{Data Collection}

The study adopts statistical survey method as it "studies the sampling of individual units from a population and the associated survey data collection techniques, such as questionnaire construction and methods for improving the number and accuracy of responses to surveys. Survey methodology includes instruments or procedures that ask 
one or more questions that may, or may not, be answered" (Beam, 2012, p. xv). Therefore, both Mongolian English majors and the English teachers are requested to fulfill a survey that aims at finding out how they assess situational English teaching method.

Table 1. Questions for the teachers' applying situational teaching to Mongolian English majors

\begin{tabular}{|c|c|c|}
\hline Item & Choice & Percentage (\%) \\
\hline In your class, how often do you use multimedia assisting & often & 80.1 \\
\hline \multirow[t]{2}{*}{ teaching? } & seldom & 19.9 \\
\hline & never & 0 \\
\hline \multirow{4}{*}{$\begin{array}{l}\text { What is students' reaction to the pictures, video, audio } \\
\text { and games you apply in class? }\end{array}$} & active participation & 65.2 \\
\hline & were asked to & 26.1 \\
\hline & were called to answer & 8.7 \\
\hline & drop out & 0 \\
\hline \multirow[t]{4}{*}{ What is students' degree of learning? } & easier & 25.7 \\
\hline & basically grasped & 58.6 \\
\hline & a bit difficult & 10.5 \\
\hline & grasp a little & 5.2 \\
\hline \multirow[t]{3}{*}{$\begin{array}{l}\text { Will you take students' interest as the most important } \\
\text { part? }\end{array}$} & $\begin{array}{l}\text { care students' interest and classroom } \\
\text { atmosphere }\end{array}$ & 80.5 \\
\hline & only in warming up part & 14.6 \\
\hline & save time to teach key points & 4.9 \\
\hline \multirow[t]{2}{*}{$\begin{array}{l}\text { Do you organize students do team work as in your } \\
\text { teaching plan? }\end{array}$} & $\begin{array}{l}\text { organize class discussion among students } \\
\text { focus on individual and choral imitation }\end{array}$ & 31.7 \\
\hline & & 68.3 \\
\hline \multirow[t]{4}{*}{ What is your teaching effect? } & better understand the text & 22.0 \\
\hline & train students' oral communication ability & 51.2 \\
\hline & students are very happy & 26.8 \\
\hline & no interest & 0 \\
\hline \multirow[t]{3}{*}{ How are your teaching activities developed? } & near to textbook & 46.3 \\
\hline & near to life & 46.3 \\
\hline & just make classroom active & 7.4 \\
\hline \multirow{3}{*}{ Do you correct the students' mistakes? } & sometimes & 20.6 \\
\hline & most of the time & 8.8 \\
\hline & seldom & 70.6 \\
\hline
\end{tabular}

Table 2. Questions for the Mongolian English Majors

\begin{tabular}{|c|c|c|}
\hline Item & Choice & Percentage $(\%)$ \\
\hline \multirow[t]{4}{*}{ Which language does the teacher speak in class? } & English & 10.0 \\
\hline & English with Chinese & 70.2 \\
\hline & English with Mongolian & 10.8 \\
\hline & English with Chinese and Mongolian & 9.0 \\
\hline \multirow[t]{2}{*}{ Does the teacher use pictures, video, audio and games? } & Yes & 100 \\
\hline & No & 0 \\
\hline \multirow{4}{*}{$\begin{array}{l}\text { What is the extent of your learning from course-ware } \\
\text { content? }\end{array}$} & easier & 12.6 \\
\hline & basically grasped & 51.2 \\
\hline & a bit difficult & 30.4 \\
\hline & grasp a little & 5.8 \\
\hline \multirow[t]{3}{*}{ What is your feedback? } & too fancy & 2.4 \\
\hline & content is too much & 29.3 \\
\hline & clear, easy to understand & 68.3 \\
\hline \multirow[t]{3}{*}{ Do you do team work and cooperate with each other? } & only talk with partner & 53.2 \\
\hline & enjoy a team work & 36.7 \\
\hline & do not like so much & 10.1 \\
\hline \multirow[t]{3}{*}{ Do you have time to think and discuss in class? } & have enough time & 68.3 \\
\hline & hurry to end & 24.4 \\
\hline & have no time & 7.3 \\
\hline \multirow[t]{3}{*}{ Do you want the teacher to correct your mistakes? } & all the time & 22.3 \\
\hline & sometimes & 62.5 \\
\hline & no & 15.2 \\
\hline
\end{tabular}




\section{Results and Discussion}

\subsection{Obstacles Existing in the Application among Mongolian English Majors}

\subsubsection{Passive Participation due to Improper Text Parsing}

Situational method highlights the students' participation consciousness. Anyway, in real practice, there are still misunderstanding existing in both learning and teaching like "improper text parsing, unreasonable situation setting and ignoring the transfer process among language, image and meaning because of the unclear goal of situational teaching". (Xie, 2014, p. 31) Text parsing is considered the first step towards a successful outcome of situational method. In Inner Mongolia University for Nationalities, Mongolian English majors are enrolled at a relatively lower score around 60-90 during College Entrance Examination, with 150 as full score. Among 72 students, 47 of them are from rural farm district where they did not receive any professional training of basic language skills. Collected statistic shows in answering the question "What is the extent of your learning from course-ware content?" More than half of the students are able to grasp basic knowledge; only a small part will feel easier. There are nearly ten percent of those who think that more difficult; nearly five percent of people think that only grasp little. The result shows that, in the daily English teaching of Mongolian class, a large part of the students are not familiar with the visible knowledge. As for the survey on teachers, the answer to the question of "what is students' reaction to pictures, video, audio, and game" shows that $63.4 \%$ of the students will take the initiative to participate in the classroom, $29.3 \%$ of students are called to participate, and very few will be afraid to be called to. This result shows the situational teaching method's purpose is arrived which is to improve students' enthusiasm. Meanwhile, it can be seen that there are still a few students unlike to participate in the classroom due to their failure to grasp the content of both the textual information and courseware. When adopting situational teaching in class, if its form is too single, lack of innovation, this teaching mode will reduce the interest of students. And then teachers fall into the traditional teaching mode; the teaching effect is greatly reduced.

\subsubsection{Weakening Role of Teachers}

In applying SLT, teachers should strengthen the students' subjectivity, but teachers' role cannot be weakened in monitoring the classroom order. Richards argues that teacher serves as a model, a skillful manipulator, and lessons are hence teacher directed (p. 38). There are a number of teachers who offer full freedom for the students award the classroom order to the students. The teachers' guidance, correcting and checking network function has not been fully exploited. Even though the classroom atmosphere is very active and students are enthusiastic, the teaching effect is not very satisfactory. The question "Do you organize students do team work as in your teaching plan?" The data from participants shows $68.3 \%$ teachers still focus on classroom discussion as they assigned. There are still some teachers who don't realize the importance of classroom interaction guided by the teacher. They let go students' ineffective conversation, faulty grammar or pronunciation in class. Most teachers choose to encourage communication among students and only a small portion of the number guides students with their group or team work because they are afraid of interrupting the students' discussion. We can find that the current problem is how to balance between the interaction of the students and the manipulating status of teachers.

\subsubsection{Ineffective Transfer among Language, Image and Meaning}

As the ancient language of Altai, Mongolian has its strict pronunciation system, writing format and grammar system. For Mongolian students, Mongolian is the native language, Chinese is the second language. Chinese becomes the bridge for Mongolian students learning English. In processing English words, they subconsciously turn them into Mongolian first. Yet there are no exact equivalents between Mongolian and English, they would fail to set up an appropriate situation. The image turns vague, and the meaning unclear. The aim of linking the students' real life with the students to understand the content better is not fulfilled.

\subsection{Relevant Strategies of the Barriers}

\subsubsection{Selecting Appropriate and Natural Situation}

Through language, we can restore true scenes of life. Appropriate and natural situation which are adoptable for English majors from Mongolian background becomes necessary. Considering trilingual influence, class designer should create scenes actual to life that Mongolian students feel at ease. The teacher should be certain that "learners can speak fairly correctly within the limits of their knowledge." (Pittmam, 1963, p. 188) Language is viewed as purposeful activity related to goals and situations in the real world (Halliday, McIntosh, \& Strevens, 1964, Chapter 4). Situations may begin with fundamental ones like greeting, introducing each other, asking about the weather, buying and selling things, eating in a restaurant and so on. For example, when we are learning introducing ourselves, teachers can introduce herself in English, "My name is..., I'm from ...." At the same time, teachers should write the sentences on the blackboard. Then ask students "What's your name? Where are you from?" When 
we are asking like this, inanimate written letters are turned to splendid information carrier in communication. For Mongolian students, their English ability is relatively weak, syntactic structure is incomplete and vocabulary storage is few. By means of material objects, it shows teachers' simple intentions and it is beneficial for students to build up vocabulary. For example, when we teach words which are about school, we can use words of classroom to deepen students' degree of familiarity. The objective of SLT is not only to speak but also to "teach a practical command of the four basic skills of language." (Richards, p. 36) Showing picture is a major means to build a presence. Actually, using pictures to create situation means making the abstract knowledge concrete. Illustrations, scrapbooks and stick figures can also create life situations.

\subsubsection{Making Situations Interesting}

In the process of English learning, applying stories to create lively situation plays an important role. On the one hand, stories which students are familiar with can lead students to specific circumstances and roles. Story contains vivid plot, enlightening experiences and certain language knowledge. It conforms to students' cognitive and psychological characteristics and help students to enter designed scenes.

Playing games is an effective measure to create situation. Teachers can set some games such as guessing words, reading poetry and tongue twister. Take quiz game for example, students can use animate actions to describe words about weather such as sunny, rainy, shining, windy, cold, hot, warm, cool, fine and so on.

Teachers need multi-media as assisted instruction. Multi-media tools can create a three dimensional effect of looking, listening and speaking which can also help students come into contact with the most unique and stereoscopic contents. Meanwhile, it can save much time as well as labor of blackboard writing and arouse students' study interest and efficiency. As teachers, preparing software is also a process of preparing lessons again since teachers should ponder contents of the text, settle knowledge frame, and consider each teaching step.

\subsubsection{Strengthening Cooperative Learning}

Data collected from Table 1 "Do you organize students do team work as in your teaching plan?" shows, 68.3\% teachers focus on individual and choral imitation; $31.7 \%$ teachers organize class discussion among students. Through classroom discussion among students, teachers and students can help the development of students' communicative competence, and thus complete the syllabus requirement. The purpose of cooperative learning is to promote students' common cooperation in the different groups and reach a common study target and groups are praised by the total result of groups (Wang, 2001). During the cooperation, understanding of different situations will be exchanged among members. Conclusions and views come out by group activities and discussions. Teachers put a good deal of energy on the design of class teaching and the arrangement of activities. As a result, they make a progress in understanding the problems of students.

\section{Conclusion}

Situational language teaching is a further development of well-established Oral Approach, and it continues to be widely used in language teaching. In applying the method to Mongolian English majors who are with less cross-cultural background information and average low fundamental language ability, there are problems existing in practice as improper text parsing, unreasonable situation setting and ignoring the transfer process among language, image and meaning. Moreover, teachers' function sometimes is undervalued. Consequently, it results in inactive participation of students and incomplete classroom procedures. For Mongolian students, they may have "no control over the content of learning and is often regarded as likely to succumb to undesirable behaviors unless skillfully manipulated by the teacher."(Richards, p. 38) Through the design of authentic scene and concrete situation, situational language method provides plenty of examples for language study. It helps activate both teaching and learning a language.

\section{References}

Beam, G. (2012). The Problem with Survey Research (p. xv). New Brunswick, NJ: Transaction.

Bloom, L., \&Karin, L. H. (1989). On the developmental contour of child language: a reply to Smith and Weist. Journal of child language, 16, 207-216. https://doi.org/10.1017/S0305000900013520

Burns, N., \& Grove, S. K. (2003). Understanding Nursing Research, Saunders, Pennsylvania.

Casey, T. (2014). Reflective practice in legal education: The stages of reflection. Clinical Law Review, 20 , 317-354.

Comenius, J. A. (2006). Great Didactics. Trans. Ren Zhongyin. Beijing: People's Education Press.

Dewey, J. Democratism and Education. Trans. Wang Chengxu. (1990). Beijing: People's Education Press. 
Halliday, M. A. K., McIntosh, A., \& Strevens, P. (1964). The Linguistic Sciences and Language Teaching. Chapter 4. London: Longman.

Odlin, T. (1989). Language Transfer: Cross-Linguistic Influence in Language Learning. Cambridge: CUP. https://doi.org/10.1017/CBO9781139524537

Pittman, G. (1963). Teaching Structural English. Brisbane: Jacaranda.

Richards, J. C., \& Theodore, S. R. (2000). Approaches and Methods in Language Teaching. Cambridge: Cambridge University Press.

Rod, E. (1994). The Study of Second Language Acquisition. Oxford: Oxford University Press.

Shu, B. M. (2009). Modern Foreign Language Teaching Methodology. Shanghai: Shanghai Foreign Language Education Press.

Turner, M., \& Gilles, F. (2010). Conceptual Integration and Formal Expression. Journal of Metaphor and Symbolic Activity, 10 (3).

Wang, Q. (2000). The Significance and Methods of the Research in Classroom Teaching. Journal of Beijing Normal University (Social Sciences), 34-43.

Wang, T. (2001). The Basic Idea of Cooperative Teaching. China Education Newspaper, (3), 51-54.

Xie, F. (2014). Reflections on Situated-Teaching for College English---Based on the Relationship among Yan (Language), Xiang (Image) and Yi (Meaning) . Dissertation for Master Degree, Central South University.

\section{Copyrights}

Copyright for this article is retained by the author, with first publication rights granted to the journal.

This is an open-access article distributed under the terms and conditions of the Creative Commons Attribution license (http://creativecommons.org/licenses/by/4.0/). 